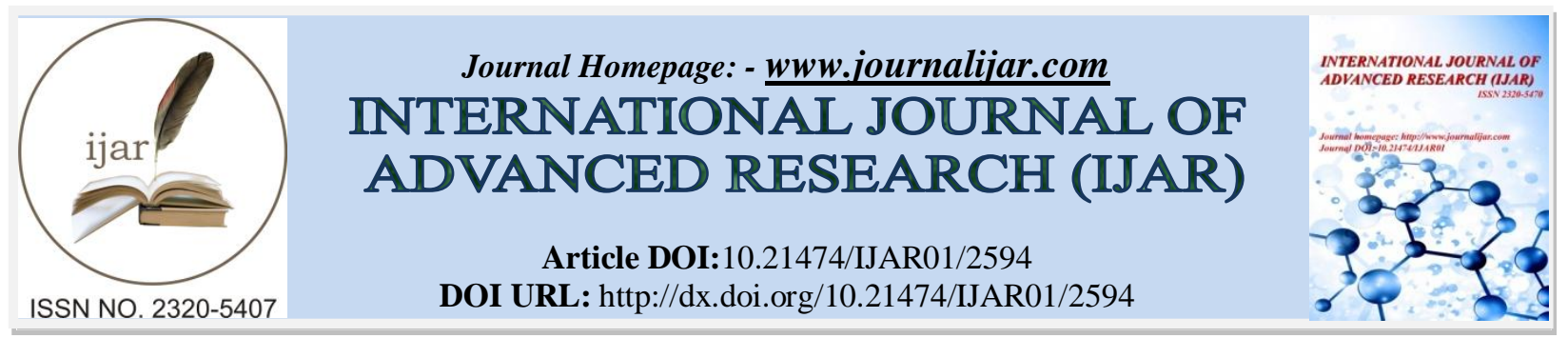

RESEARCH ARTICLE

\title{
VANADIUM (V) COMPLEXES CONTAINING 1, 2, 4-TRIAZOLE MOIETY AND THEIR ANTIMICROBIAL ACTIVITY.
}

\author{
Mohamed Abdelbaset ${ }^{* 1,2}$ and Sami A. Zabin ${ }^{1}$. \\ 1. Chemistry Department, Faculty of Science, AlBaha University, Al-Baha, KSA. \\ 2. Chemistry Department, Faculty of Science, Al Azhar University, Assiut Branch, Assiut 71524, Egypt.
}

\section{Manuscript Info}

...........................

Manuscript History

Received: 27 October 2016

Final Accepted: 25 November 2016

Published: December 2016

Key words:-

1,2,4-Triazole moiety, Vanadium(V)

complexes, Antibacterial activity

\section{Abstract}

Novel oxo-/dioxo-vanadium(V) complexes with the bidentate 4amino-5-mercapto-3-phenyl-1,2,4-triazole $\left(\mathrm{L}_{1}\right)$ and the tridentate 4Amino-3-hydrazino-5-mercapto-1,2,4-triazole $\left(\mathrm{L}_{2}\right)$ ligands have been synthesized and characterized using elemental analysis, IR, ${ }^{1} \mathrm{H}-\mathrm{NMR}$, electronic spectra and thermal studies.

Both ligands $\left(\mathrm{L}_{1}\right.$ and $\left.\mathrm{L}_{2}\right)$ coordinate to the vanadium ions through sulphur and nitrogen toms. The results indicate thatthe prepared vanadium $(V)$ complexes exhibited distorted square-pyramidal geometry. The antimicrobial activities of the ligands and their complexes show moderate activity.The results showed enhanced activity of metal complexes over their parent ligands.

Copy Right, IJAR, 2016,. All rights reserved.

\section{Introduction:-}

It is known that ligands containing heterocyclic ring play an important role in the development of coordination chemistry[1-2]. In the literature, it is shown that ligands with five-membered ring systems such astriazoles represent an interesting class of compounds due to the presence of three nitrogen atomsthat can coordinate to the metal ions [3-5].

Ligands with 1,2,4-Triazole derivatives represent a suitable class of five-membered heterocyclic compounds that can coordinate to the transition metals and are of great importance for the preparation of new drugs with diverse biological activities [6 -7]. Many compounds containing 1,2,4-Triazole moiety and their derivatives are found to be associated with various biological activities such as antibacterial, antifungal, analgesic, anticancer, antiviral, antitubercular, anti-inflammatory, anticonvulsant, antidepressant [8-22]. In addition, it is shown that these compounds have influence on the central nervous system (CNS) as anticonvulsive and potent antinociceptive activity[23]. Many drugs containing 1,2,4-triazole rings are well known such as fluconazole used in the treatment and prevention of superficial and systemic fungal infections, [24], vorozole, letrozole [25] and anastrozole [26] are nonsteroidal drugs used for the treatment of cancer [27] and loreclezole is used as an anticonvulsant [28].

The ligands with 1,2,4-triazolemoeity show a great coordination diversity, especially when the triazole nucleus issubstituted with additional donor groups. When the triazole ring has other coordination groups such as $\mathrm{NH}_{2}, \mathrm{OH}$, $\mathrm{NH}-\mathrm{NH}_{2}$ or $\mathrm{SH}$ the triazole unit can coordinate in many different ways [29-33]. According to our literature survey, no vanadium $(\mathrm{V})$ complexes containing 1,2,4-triazole ring with hydrazine, amino and thiol groups are found. 
Based on the above mentioned importance and properties, we thought that it is interesting to synthesize a new complexes containing vanadium (v) as central metal atom with two types of ligands containing 1,2,4-triazole ring. The ligands used in this work are: 4-amino-5-mercapto-3-phenyl-1,2,4-triazole $\left(\mathrm{L}_{1}\right)$ and 4-Amino-3-hydrazino-5mercapto-1,2,4-triazole $\left(\mathrm{L}_{2}\right)$. This investigation was devoted for the synthesis, characterization and examining the biological activity of the synthesized compounds. The structural features of the metal complexes have been elucidated by various spectral and analytical techniques.

\section{Materials and Methods:-}

\section{Chemicals:-}

All chemicals used in this work $\mathrm{NH}_{4} \mathrm{VO}_{3}, \mathrm{~N}(\mathrm{Pr})_{4} \mathrm{OH}, \mathrm{N}(\mathrm{Me})_{4} \mathrm{OH}$, 4-Amino-3-hydrazino-5-mercapto-1,2,4triazole $\left(\mathrm{L}_{2}\right)$ were purchased from Sigma-Aldrich and used as received without purification. The 4-amino-5mercapto-3-phenyl-1,2,4-triazole $\left(\mathrm{L}_{1}\right)$ has been synthesized according to the reported methods [34] Fig. 1.

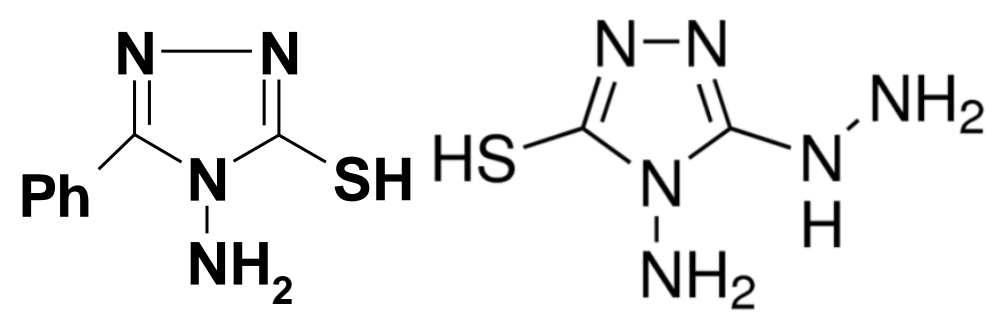

$\mathrm{L}_{1} \quad \mathrm{~L}_{2}$

Fig. 1:-.ligands $\mathrm{L}_{1}$ and $\mathrm{L}_{2}$

\section{Preparation of Metal Complexes:-}

$\mathrm{NH}_{4}\left[\mathrm{VO}\left(\mathrm{L}_{1}\right)_{2}\right] 3 \mathrm{H}_{2} \mathrm{O}(1):-$

To a hot magnetically stirred $(50 \mathrm{~mL})$ ethanolic solution of the ligand 1 (2mmol), a solution of $\mathrm{NH}_{4} \mathrm{VO}_{3}(0.117 \mathrm{~g}, 1$ $\mathrm{mmol}$ ) in $30 \mathrm{ml}$ hot water was added slowly with stirring. The mixture was stirred and heated directly on a wire gauze for one hour during which a precipitated product was formed. The precipitates were filtered, washed with methanol, dioxane and then with diethyl ether and dried under vacuum. The yield obtained was of $75 \%$.

$\mathrm{NH}_{4}\left[\mathrm{VO}_{2}\left(\mathrm{~L}_{2}\right)\right] 3 \mathrm{H}_{2} \mathrm{O}(2):-$

Prepared by the same procedure as for 1 but using ligand $2(2 \mathrm{mmol})$ in $50 \mathrm{~mL}$ methanol. The yield obtained was of $70 \%$.

$\mathrm{N}(\mathrm{Me})_{4}\left[\mathrm{VO}\left(\mathrm{L}_{1}\right)_{2}\right] 3 \mathrm{H}_{2} \mathrm{O}(3):-$

$\mathrm{NMe}_{4} \mathrm{OH}(0.36 \mathrm{ml}, 1 \mathrm{mmol}, 35 \%)$ was added to a solution of $\mathrm{NH}_{4} \mathrm{VO}_{3}(0.117 \mathrm{~g}, 1 \mathrm{mmol})$ in $20 \mathrm{ml}$ hot water. The ammonia evolved was removed from the resulting solution by boiling. The obtained solution mixture was cooled and added to a solution of ligand $1(2 \mathrm{mmol})$ in $30 \mathrm{ml}$ methanol slowly with heating and stirring using hot plate stirrer. The solid complexes separated out were filtered at hot condition. Then washed with hot methanol and petroleum ether to remove the unreacted ligand andthen dried under vacuum. The yield obtained was of $65 \%$.

\section{$\mathrm{N}(\mathrm{Me})_{4}\left[\mathrm{VO}_{2}\left(\mathrm{~L}_{2}\right)\right] 3 \mathrm{H}_{2} \mathrm{O}(4)$ :-}

Prepared by the same procedure as for 3 but using ligand $2(1 \mathrm{mmol})$ in $50 \mathrm{~mL}$ methanol. The yield obtained was $60 \%$.

$\mathrm{N}(\operatorname{Pr})_{4}\left[\mathrm{VO}\left(\mathrm{L}_{1}\right)_{2}\right] 3 \mathrm{H}_{2} \mathrm{O}(5):-$

$\mathrm{NH}_{4} \mathrm{VO}_{3}(0.117 \mathrm{~g}, 1 \mathrm{mmol})$ was dissolved under stirring in $1 \mathrm{~mL}$ of $1 \mathrm{mmol} \mathrm{NPr} r_{4} \mathrm{OH}$ solution and $\mathrm{NH}_{3}$ was removed from the solution by boiling. After cooling of the resulting solution, added to a solution of ligand 1 ( $2 \mathrm{mmol}$ ) in 50 $\mathrm{ml}$ methanol. The solid complexes separated were filtered in hot condition. The precipitates washed with hot ethanol and petroleum ether to remove unreacted ligandand then dried under vacuum. The yield obtained was $75 \%$.

$\mathrm{N}(\operatorname{Pr})_{4}\left[\mathrm{VO}_{2}\left(\mathrm{~L}_{2}\right)\right] 3 \mathrm{H}_{2} \mathrm{O}(6):-$

Prepared by the same procedure as for 3 using ligand $2(1 \mathrm{mmol})$ in $50 \mathrm{~mL}$ methanol. The yield obtainedwas $65 \%$. 


\section{Physical Measurements and Analytical Methods:-}

Melting points were measured on Electrothermal (Cat NO. TA9100) melting point apparatus.Carbon, hydrogen, nitrogen and sulphur were analyzed micro analytically using CHNS analyzer Leco Model VTF-900 CHN-S-O 932 version 1.3x (ThermoFisher Scientific-USA) instrument. Electronic spectra of the solutions of the complexes in $10^{-5}$ MDMSO were recorded onEvolution 300 UV-visibledouble beam Spectrophotometer. FT- IR spectra $\left(400-4000 \mathrm{~cm}^{-}\right.$ ${ }^{1}$ ) were recorded as KBr discs using Nicolet IS50 FT-IR spectrophotometer. Thermo gravimetric (TGA) studies was recorded on Shimadzu thermo-analyzer 50 in a dynamic nitrogen atmosphere $(100 \mathrm{ml} / \mathrm{min})$ at a heating rate $10^{\circ} \mathrm{C} / \mathrm{min}$ in an atmosphere of nitrogen in the temperature range $25-1000{ }^{\circ} \mathrm{C}$. Circular NMR spectra were obtained in $\mathrm{CD}_{3} \mathrm{OD}$ solutions with a Varian Mercury-400BB $(400 \mathrm{MHz})$ spectrometer using TMS $\left({ }^{1} \mathrm{H}\right)$ as standard.

\section{Antimicrobial Activity:-}

To assess the microbial susceptibility of the vanadium (V) complexes and their parent ligands, the synthesized compounds were examined against six types of pathogenic bacteria (Staphylococcus aureus, Enterococcus faecalis, and Group B streptococcus (GBS)) as Gram-positive bacteria, and (Proteus Mirabilis, Escherichia coli, Klebsiellapneumoniae) as Gram-negative bacteria.In addition, the compounds were tested against one kind of fungi (Candida Albicans).

Well Diffusion Assay method as the susceptibility testing method was used perform the antibacterial and antifungal activities test $[1,35]$. The antimicrobial activities were tested for their in vitro growth inhibitory activity against the bacterial and fungal strains cultured on the surface of a sterile Muller-Hinton agar as growth medium. The stock solutions of the compounds were prepared by dissolving $0.02 \mathrm{gm}$ of each tested compound in $5 \mathrm{~mL}$ DMSO solvent. A small hole was made in the middle of each dish using sterile metal cork borer $(5 \mathrm{~mm})$. Then, Solutions of the ligands $\mathrm{L}_{1}$ and $\mathrm{L}_{2}$ and their corresponding vanadium complexes in DMSO were poured into the holes made in the cultured agar medium and incubated at $37^{\circ} \mathrm{C}$ for a period of 24 hours. The microbial susceptibilitieswere monitored by measuring the zones of inhibition (in $\mathrm{cm}$ ) around each hole after the incubation period. All samples were repeated in triplicate, and statistical analysis were performed using SPSS 16.0 for windows. Thep-values $<0.05$ were considered statistically significant for the statistical purpose. In addition, we have performed the antifungal susceptibility against Candida albicansof the organic ligands $\mathrm{L}_{1}$ and $\mathrm{L}_{2}$ and their corresponding vanadium complexes using the solid form of the compounds by spreading the solid powder $(0.02 \mathrm{gm})$ on the surface of the Muller-Hinton agar medium.

\section{Results and Discussion:-}

The structures of the synthesized compounds have been characterized by UV-visible, FT-IR, ${ }^{1} \mathrm{H}-\mathrm{NMR}$ spectrum, thermal analyses and elemental analysis. All synthesized complexes were colored solids and stable at room temperature to air and moisture. All complexes were insoluble in water and alcohols but soluble in DMF and DMSO. The vanadium complexes have melting points above $300{ }^{\circ} \mathrm{C}$. The elemental analysis data is presented in table 1.From the elemental analysis data it is evident that the complexes were of two types:1:2 (M: $\left.\mathrm{L}_{1}\right)$ ratio in case of the ligand $\mathrm{L}_{1}$ and 1:1 $\left(\mathrm{M}: \mathrm{L}_{2}\right)$ in case of ligand $\left.\mathrm{L}_{2}\right)$. The analytical data results obtained for the complexes were in good agreement with the proposed structuresas shown in schemes 1 and 2.The analytical and spectroscopic results showed that all vanadium $(\mathrm{V})$ complexes are monomeric in nature. 
Table 1: The elemental analysis data ofthe ligands and their Vanadium (V) Complexes

\begin{tabular}{|c|c|c|c|c|c|c|c|}
\hline \multirow[t]{2}{*}{ Compound } & \multirow[t]{2}{*}{ Mol.Formula } & \multirow[t]{2}{*}{ Mol.Wt. } & \multicolumn{5}{|c|}{ Cald(Found) $\%$} \\
\hline & & & C & $\mathrm{H}$ & $\mathrm{N}$ & $\mathrm{O}$ & $\mathrm{S}$ \\
\hline $\mathrm{L}_{1}$ & $\mathrm{C}_{8} \mathrm{H}_{8} \mathrm{~N}_{4} \mathrm{~S}$ & 192.24 & $\begin{array}{l}49.98 \\
(49.60)\end{array}$ & $\begin{array}{l}4.19 \\
(3.95)\end{array}$ & $\begin{array}{l}29.14 \\
(29.6)\end{array}$ & - & $\begin{array}{l}16.68 \\
(16.72)\end{array}$ \\
\hline $\mathrm{NH}_{4}\left[\mathrm{VO}\left(\mathrm{L}_{1}\right)_{2}\right] 3 \mathrm{H}_{2} \mathrm{O}$ & $\mathrm{C}_{16} \mathrm{H}_{24} \mathrm{~N}_{9} \mathrm{~S}_{2} \mathrm{O}_{4} \mathrm{~V}$ & 521.49 & $\begin{array}{l}36.85 \\
(36.72)\end{array}$ & $\begin{array}{l}4.63 \\
(4.80)\end{array}$ & $\begin{array}{l}24.17 \\
(24.35)\end{array}$ & $\begin{array}{l}12.27 \\
(11.95)\end{array}$ & $\begin{array}{l}12.29 \\
(12.50)\end{array}$ \\
\hline $\mathrm{N}(\operatorname{Pr})_{4}\left[\mathrm{VO}\left(\mathrm{L}_{1}\right)_{2}\right] 3 \mathrm{H}_{2} \mathrm{O}$ & $\mathrm{C}_{28} \mathrm{H}_{48} \mathrm{~N}_{9} \mathrm{~S}_{2} \mathrm{O}_{4} \mathrm{~V}$ & 689.81 & $\begin{array}{l}48.75 \\
(48.93)\end{array}$ & $\begin{array}{l}7.01 \\
(7.33)\end{array}$ & $\begin{array}{l}18.27 \\
(17.90)\end{array}$ & $\begin{array}{l}9.27 \\
(9.55)\end{array}$ & $\begin{array}{l}9.29 \\
(9.15)\end{array}$ \\
\hline $\mathrm{N}(\mathrm{Me})_{4}\left[\mathrm{VO}\left(\mathrm{L}_{1}\right)_{2}\right] 3 \mathrm{H}_{2} \mathrm{O}$ & $\mathrm{C}_{20} \mathrm{H}_{32} \mathrm{~N}_{9} \mathrm{~S}_{2} \mathrm{O}_{4} \mathrm{~V}$ & 577.59 & $\begin{array}{l}41.58 \\
(41.72)\end{array}$ & $\begin{array}{l}5.58 \\
(5.20)\end{array}$ & $\begin{array}{l}21.82 \\
(21.62)\end{array}$ & $\begin{array}{l}11.08 \\
(11.52)\end{array}$ & $\begin{array}{l}11.10 \\
(11.25)\end{array}$ \\
\hline $\mathrm{L}_{2}$ & $\mathrm{C}_{2} \mathrm{H}_{6} \mathrm{~N}_{6} \mathrm{~S}$ & 146.17 & $\begin{array}{l}16.43 \\
(16.40)\end{array}$ & $\begin{array}{l}4.13 \\
(4.10)\end{array}$ & $\begin{array}{l}57.49 \\
(57.55)\end{array}$ & - & $\begin{array}{l}21.93 \\
(21.95)\end{array}$ \\
\hline $\mathrm{NH}_{4}\left[\mathrm{VO}_{2}\left(\mathrm{~L}_{2}\right)\right] 3 \mathrm{H}_{2} \mathrm{O}$ & $\mathrm{C}_{2} \mathrm{H}_{15} \mathrm{~N}_{7} \mathrm{O}_{5} \mathrm{SV}$ & 300.19 & $\begin{array}{l}8.00 \\
(8.26)\end{array}$ & $\begin{array}{l}5.03 \\
(5.30)\end{array}$ & $\begin{array}{l}32.66 \\
(32.25)\end{array}$ & $\begin{array}{l}26.64 \\
(26.42)\end{array}$ & $\begin{array}{l}10.68 \\
(10.50)\end{array}$ \\
\hline $\mathrm{N}(\mathrm{Pr})_{4}\left[\mathrm{VO}_{2}\left(\mathrm{~L}_{2}\right)\right] 3 \mathrm{H}_{2} \mathrm{O}$ & $\mathrm{C}_{14} \mathrm{H}_{33} \mathrm{~N}_{7} \mathrm{O}_{5} \mathrm{SV}$ & 462.46 & $\begin{array}{l}36.36 \\
(35.95)\end{array}$ & $\begin{array}{l}7.19 \\
(7.35)\end{array}$ & $\begin{array}{l}21.20 \\
(21.55)\end{array}$ & $\begin{array}{l}17.29 \\
(16.96)\end{array}$ & $\begin{array}{l}6.93 \\
(7.22)\end{array}$ \\
\hline $\mathrm{N}(\mathrm{Me})_{4}\left[\mathrm{VO}_{2}\left(\mathrm{~L}_{2}\right)\right] 3 \mathrm{H}_{2} \mathrm{O}$ & $\mathrm{C}_{6} \mathrm{H}_{17} \mathrm{~N}_{7} \mathrm{O}_{5} \mathrm{SV}$ & 350.24 & $\begin{array}{l}20.57 \\
(20.76)\end{array}$ & $\begin{array}{l}4.89 \\
(5.12)\end{array}$ & $\begin{array}{l}27.99 \\
27.63)\end{array}$ & $\begin{array}{l}22.84 \\
(23.21)\end{array}$ & $\begin{array}{l}9.15 \\
(9.61)\end{array}$ \\
\hline
\end{tabular}

\section{IR spectra:-}

The FT-IR absorption spectra of the ligands $\left(\mathrm{L}_{1}\right.$ and $\left.\mathrm{L}_{2}\right)$ and their corresponding vanadium complexes arepresented in table 2. A representative IR spectrum for $\mathrm{NH}_{4}\left[\mathrm{VO}_{2}\left(\mathrm{~L}_{2}\right)\right] .3 \mathrm{H}_{2} \mathrm{O}$ complex is shown in figure 2. The IR spectrum of the ligands $\left(\mathrm{L}_{1}\right.$ and $\left.\mathrm{L}_{2}\right)$ show bands in the regions $3370-3120 \mathrm{~cm}^{-1}$ which can be assigned to $v\left(\mathrm{NH}_{2}\right)$, and in the regions $2810-2930 \mathrm{~cm}^{-1}$ due to thiol group $v(\mathrm{OH})$ disappeared in metal complexeswhich indicates the deprotonation and coordination through $\mathrm{S}$ atom to metal ion [36-37].

In case of the complexes these bands were slightly shifted to lower positions indicating that the $\mathrm{N}$ of the amino groupare linked with the vanadium metal ion [38]. The complexes display a sharp band in the region $986-945 \mathrm{~cm}^{-1}$ due to the $v(\mathrm{~V}=\mathrm{O})$ mode (39). In the IR spectrum of the vanadium complexes of the $\mathrm{L}_{2}$ Ligand two absorption bands were observed at the range of 920 and $930 \mathrm{~cm}^{-1}$. These bands can be assigned to symmetrical $(\mathrm{O}=\mathrm{V}=\mathrm{O})$ and asymmetrical $(\mathrm{O}=\mathrm{V}=\mathrm{O})$ streching vibrations respectively, which are expected for dioxovanadium(V) compounds [40 - 44]. The IR spectrum of vanadium (V) complexes of both the ligands in the solid state shows signals above 900 $\mathrm{cm}^{-1}$. These values supports the proposed structure of square pyramidal geometry, since it is known that $v(\mathrm{~V}=\mathrm{O})$ modes are always above $900 \mathrm{~cm}^{-1}$ for vanadium complexes having such coordination geometry [45]

New bands were observed in the regions of $615-580 \mathrm{~cm}^{-1} 520-440 \mathrm{~cm}^{-1}$ in the spectra of the complexes which can be assigned to $v$ M-N and $v$ M-S respectively $(29,33,46]$. A broad band was observed at $3380-3200 \mathrm{~cm}^{-1}$ in all the spectra of complexes, assigned to a $\mathrm{vO}-\mathrm{H}$ and related to the presence of water molecules in the crystal lattice of the complexes [46, 47-50].

Table 2:- IR Spectroscopic data $\left(\mathrm{cm}^{-1}\right)$ of the ligands and their vanadium $(\mathrm{V})$ complexes.

\begin{tabular}{|l|l|l|l|l|l|l|}
\hline Compound & $\mathrm{H}_{2} \mathrm{O}$ & $\mathrm{NH}_{2}$ & $\mathrm{SH}$ & $\mathrm{V}=\mathrm{O}$ & $\mathrm{V}-\mathrm{S}$ & $\mathrm{V}-\mathrm{N}$ \\
\hline $\mathrm{L}_{1}$ & - & 3350 & 2930 & - & - & - \\
\hline $\mathrm{NH}_{4}\left[\mathrm{VO}\left(\mathrm{L}_{1}\right)_{2}\right] 3 \mathrm{H}_{2} \mathrm{O}$ & 3260 & 3260 & & 945,986 & 486 & 581 \\
\hline $\mathrm{N}(\mathrm{Pr})_{4}\left[\mathrm{VO}\left(\mathrm{L}_{1}\right)_{2}\right] 3 \mathrm{H}_{2} \mathrm{O}$ & 3200 & 3200 & & 980 & 440 & 590 \\
\hline $\mathrm{N}(\mathrm{Me})_{4}\left[\mathrm{VO}\left(\mathrm{L}_{1}\right)_{2}\right] 3 \mathrm{H}_{2} \mathrm{O}$ & 3380 & 3120 & & 950 & 460 & 580 \\
\hline $\mathrm{L}_{2}$ & - & 3250, & 2910 & - & - & - \\
& & 3200 & & & & \\
\hline $\mathrm{NH}_{4}\left[\mathrm{VO}_{2}\left(\mathrm{~L}_{2}\right)\right] 3 \mathrm{H}_{2} \mathrm{O}$ & 3370 & 3370 & & 970 & 520 & 615 \\
\hline $\mathrm{N}(\operatorname{Pr})_{4}\left[\mathrm{VO}_{2}\left(\mathrm{~L}_{2}\right)\right] 3 \mathrm{H}_{2} \mathrm{O}$ & 3250 & 3120 & & 970 & 450 & 580 \\
\hline $\mathrm{N}(\mathrm{Me})_{4}\left[\mathrm{VO}_{2}\left(\mathrm{~L}_{2}\right)\right] 3 \mathrm{H}_{2} \mathrm{O}$ & 3260 & 3130 & & 980 & 460 & 590 \\
\hline
\end{tabular}




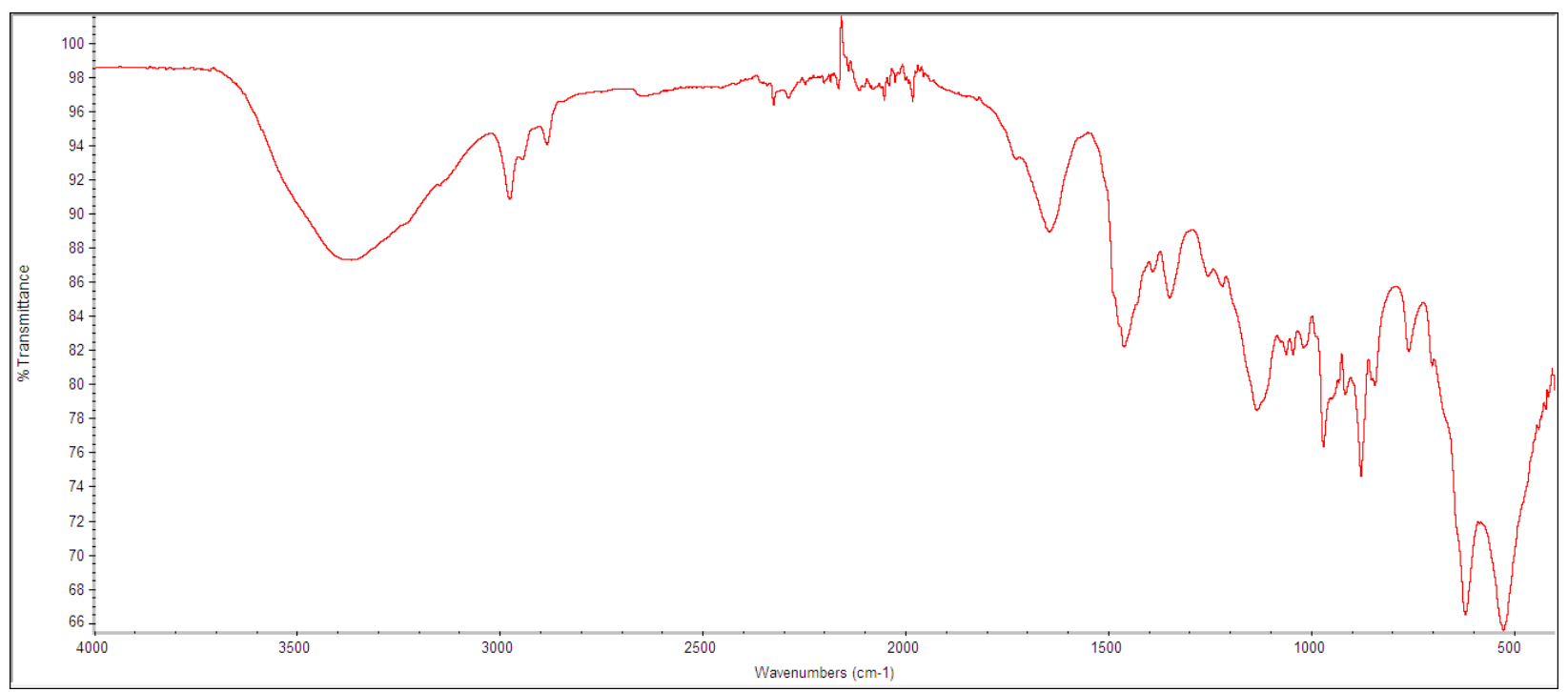

Fig. 2:- IR spectrum for $\mathrm{NH}_{4}\left[\mathrm{VO}_{2}\left(\mathrm{~L}_{2}\right)\right] \mathrm{H}_{2} \mathrm{O}$ complex.

\section{UV-Vis spectra:-}

The electronic spectral of the ligands and their vanadium complexes were recorded in $10^{-5} \mathrm{M}$ DMSO solutions, and some representative spectra are shown in figure 3 . The complexes show different characteristic $\lambda_{\max }$, compared with the ligand and this was another indication for occurrence of coordination [51 -54]. The UV spectrum of the vanadium $(\mathrm{V})$ complexes with the ligands $\left(\mathrm{L}_{1}\right.$ and $\left.\mathrm{L}_{2}\right)$ (fig. 3.) exhibit one absorption band at $\lambda_{\max }$ within the region $277-280 \mathrm{~nm} 350 \mathrm{~nm}$ to $405 \mathrm{~nm}$ with a small shoulder at $370 \mathrm{~nm}$, and these can be assigned to LMCT transitions[55]. There was no evidence of any d-d transitions. These results are consistent with the presence of vanadium (V) system in the synthesized complexes and are close to reported values for other monoperoxovanadium(V) complexes [55, 56].

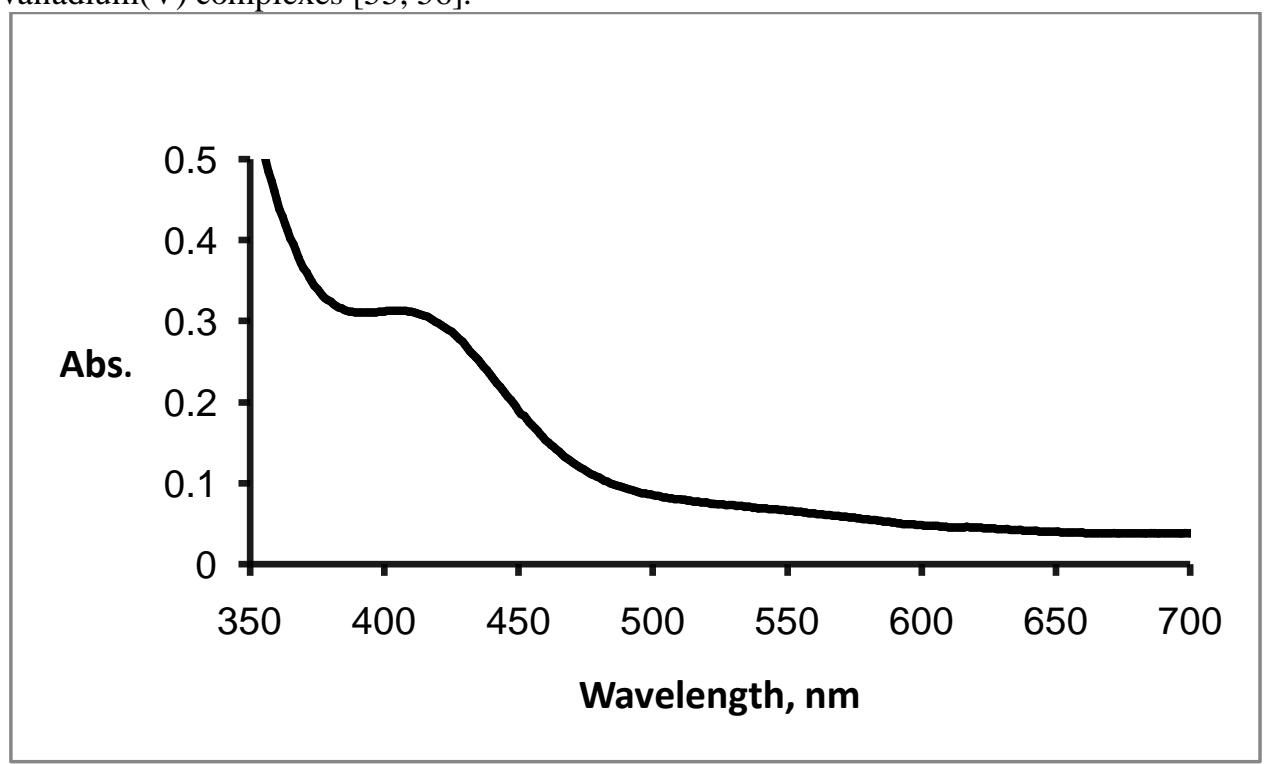

Fig. 3:- The electronic spectrum of $(\mathrm{Pr})_{4}\left[\mathrm{VO}_{2}\left(\mathrm{~L}_{2}\right)\right] 3 \mathrm{H}_{2} \mathrm{O}$ complex .

TGA studies:-

The thermal behavior of the representative complex $\mathrm{NH}_{4}\left[\mathrm{VO}_{2}\left(\mathrm{~L}_{1}\right)_{2}\right] \cdot 3 \mathrm{H}_{2} \mathrm{O}$ was investigated by means of TGA measurement under $\mathrm{N}_{2}$ atmosphere up to $650{ }^{\circ} \mathrm{C}$ at heating rate $10{ }^{\circ} \mathrm{C} / \mathrm{min}$.. The TGA curve (Fig. 4) gave information about the thermal stability and the product formed on heating. The figure shows initially a weight loss starting from $50-100{ }^{\circ} \mathrm{C}$ that corresponds to weight loss of $10.41 \%$. This can be attributed to the liberation of three outer sphere water molecules (theoretical weight loss $10.35 \%$ ). On heating from $100-350{ }^{\circ} \mathrm{C}$ shows a gradual weight loss of $33.33 \%$ Which corresponds to the removal of $\mathrm{NH}_{3}$ gasand two $\mathrm{C}_{6} \mathrm{H}_{6}$ molecules (theoretical weight loss 
33.10) [57, 58]. The weight loss continues beyond this temperature up to $650^{\circ} \mathrm{C}$ (observed $37.6 \%$ and calculated $37.10 \%$ ) attributed to the loss of two moles of triazole ring, that requires more energy, viz, higher temperatures leaving Vanadium oxide as residue.Finally attains a constant mass and composition of the complex as 1:2which is also supported by $\mathrm{C}, \mathrm{H}, \mathrm{N}, \mathrm{S}$ analyses $[38,59]$.

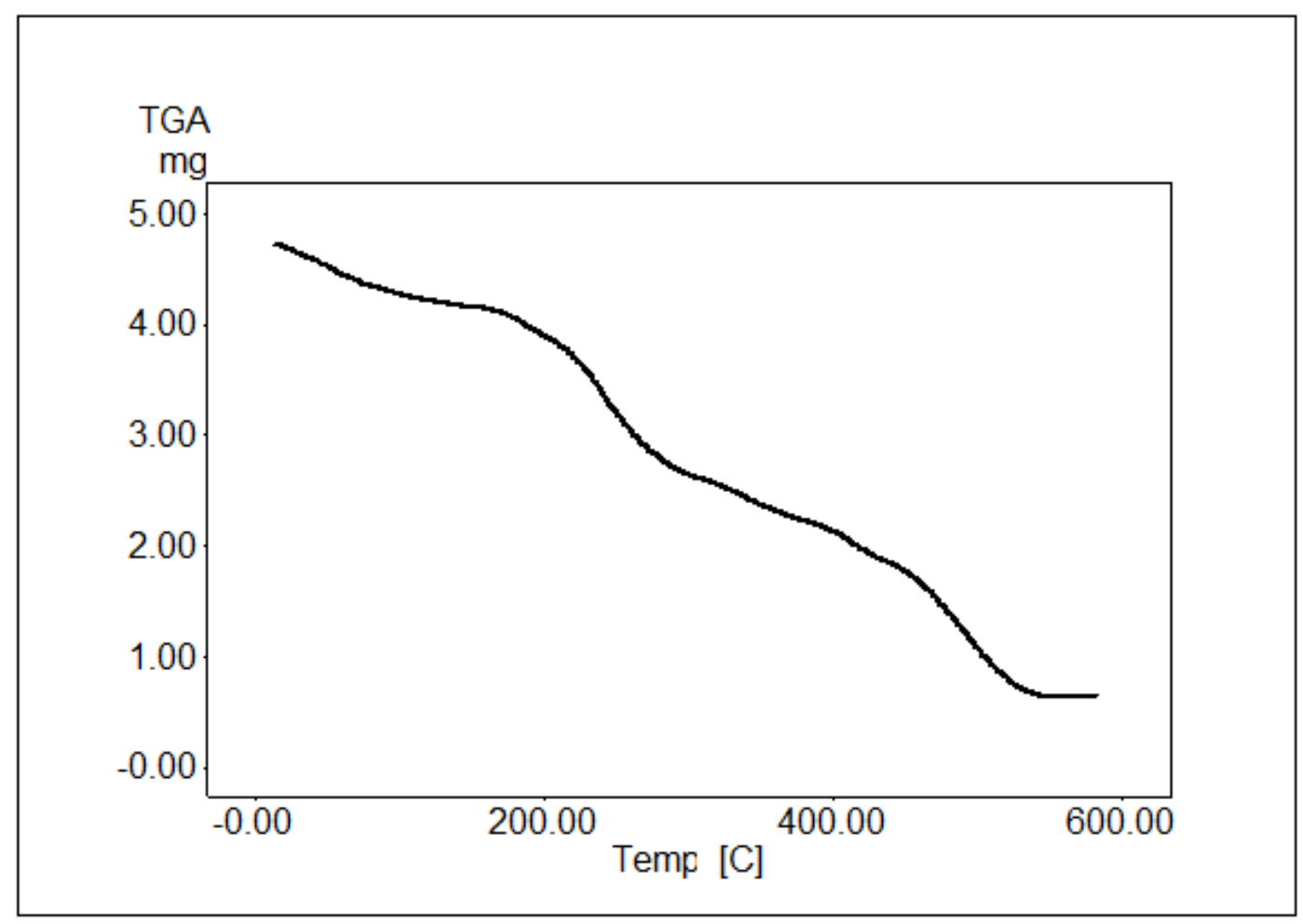

Fig. 4:- Thermogravimetric (TGA) curve of $\mathrm{NH}_{4}\left[\mathrm{VO}\left(\mathrm{L}_{1}\right)_{2}\right] 3 \mathrm{H}_{2} \mathrm{O}$ complex.

${ }^{1} \mathrm{H}$ NMR spectra:-

${ }^{1} \mathrm{H}$ NMR spectra of the ligands and their $\mathrm{V}(\mathrm{V})$ complexes have been recorded in DMSOd6using tetramethyl silence (TMS) as internal standard. The ${ }^{1} \mathrm{H}$ NMR spectra of the ligand $\mathrm{L}_{1}$ show the $-\mathrm{SH}$ proton at $10.189 \mathrm{ppm}$, which was disappeared in the spectrum of the vanadium complexes supporting the deprotonation of the thiol group and coordination through the sulphur atom with the central metal ion [30, 32].

Also, in the ${ }^{1} \mathrm{H}$ NMR Spectra (fig. 5) the signalsof $\mathrm{NH}_{2}$ protons appear at $\delta 5.76 \mathrm{ppm}$ [34]. These signals shifted to high field in the spectra of theVanadium complexes (V)indicating bonding through the nitrogen atomof the amine group to the central vanadium ion. 


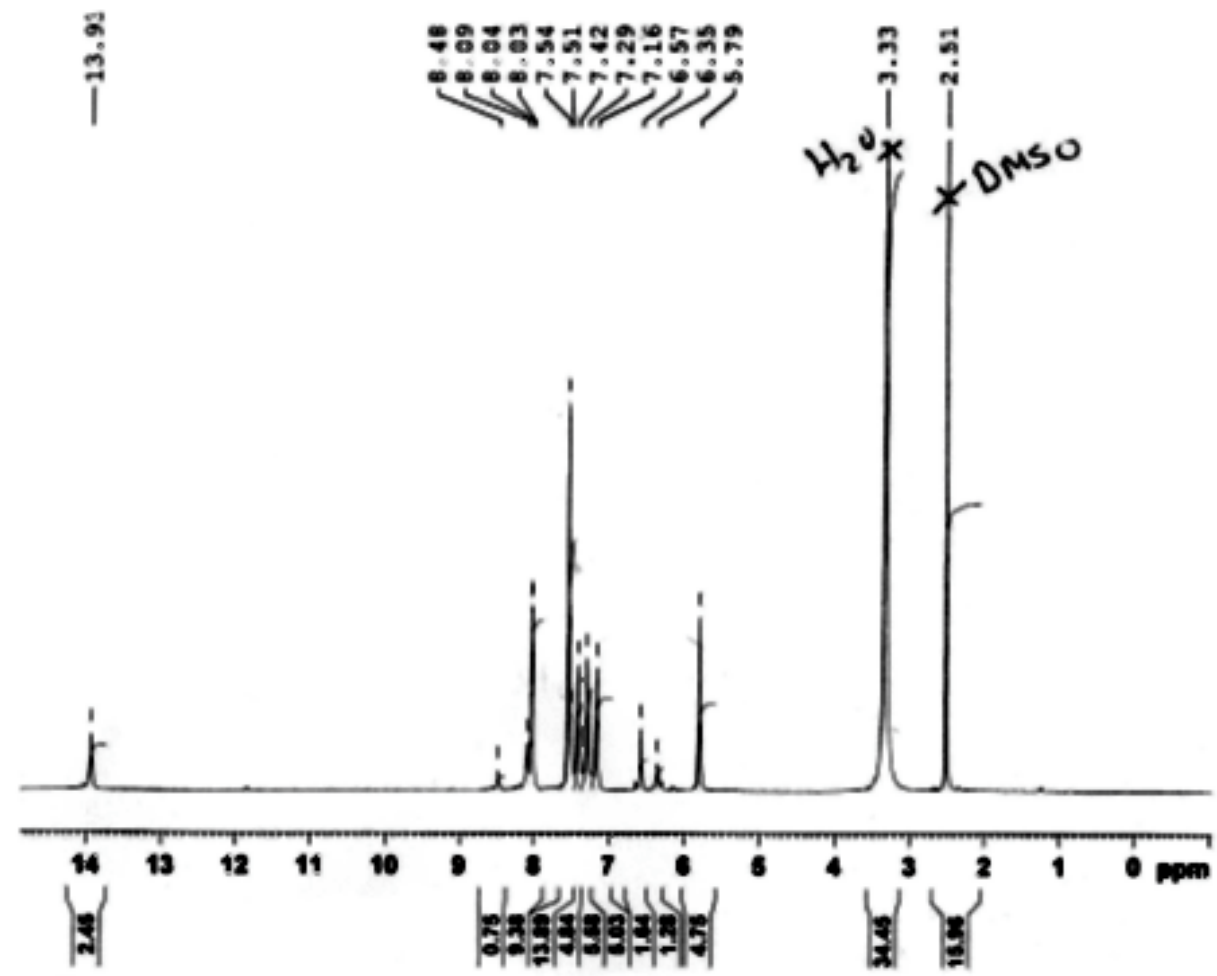

Fig.5:- ${ }^{1} \mathrm{H}$ NMR spectrum of $\mathrm{NH}_{4}\left[\mathrm{VO}\left(\mathrm{L}_{1}\right)_{2}\right] 3 \mathrm{H}_{2} \mathrm{Ocomplex}$. 


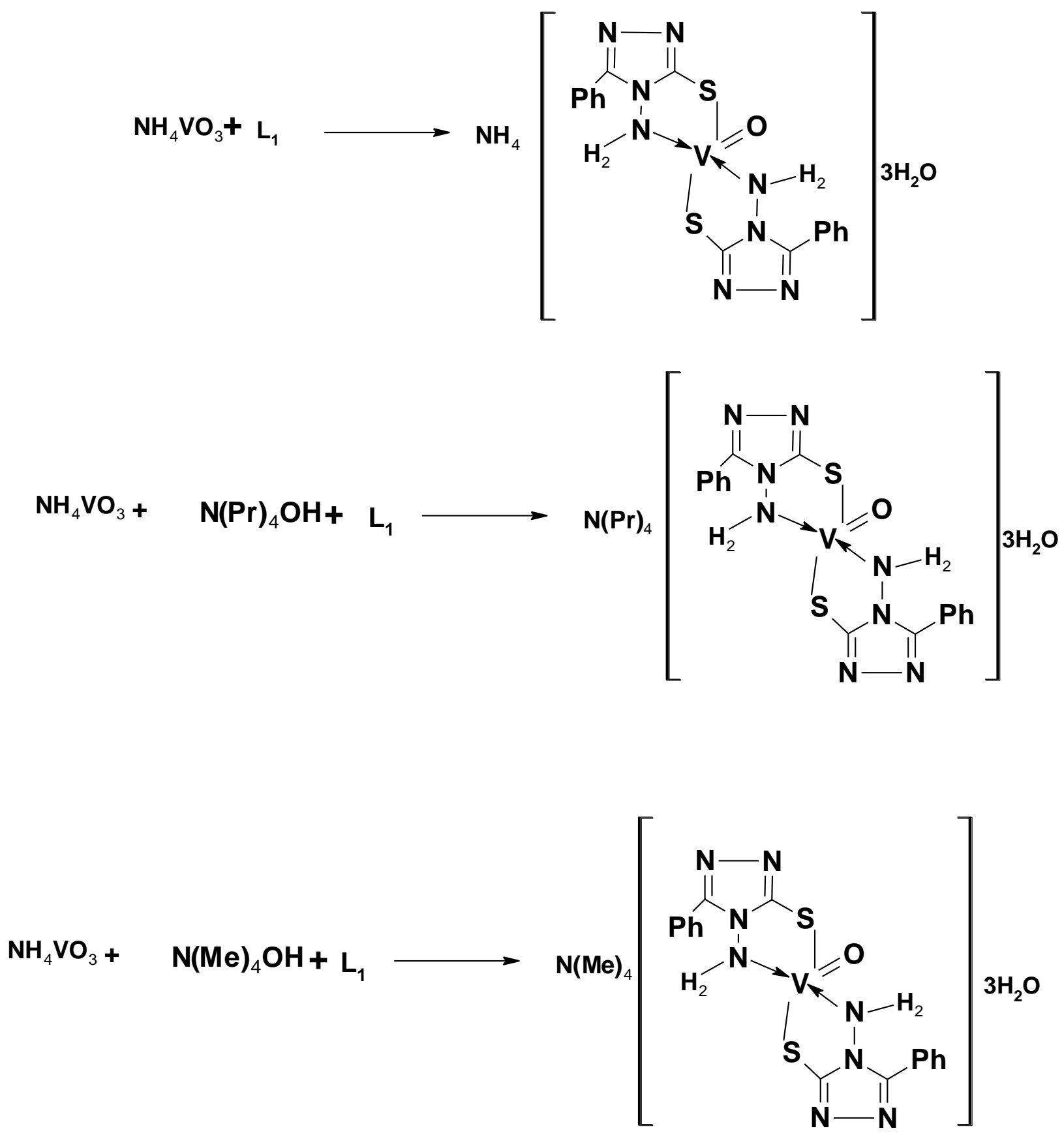

Scheme 1:- 

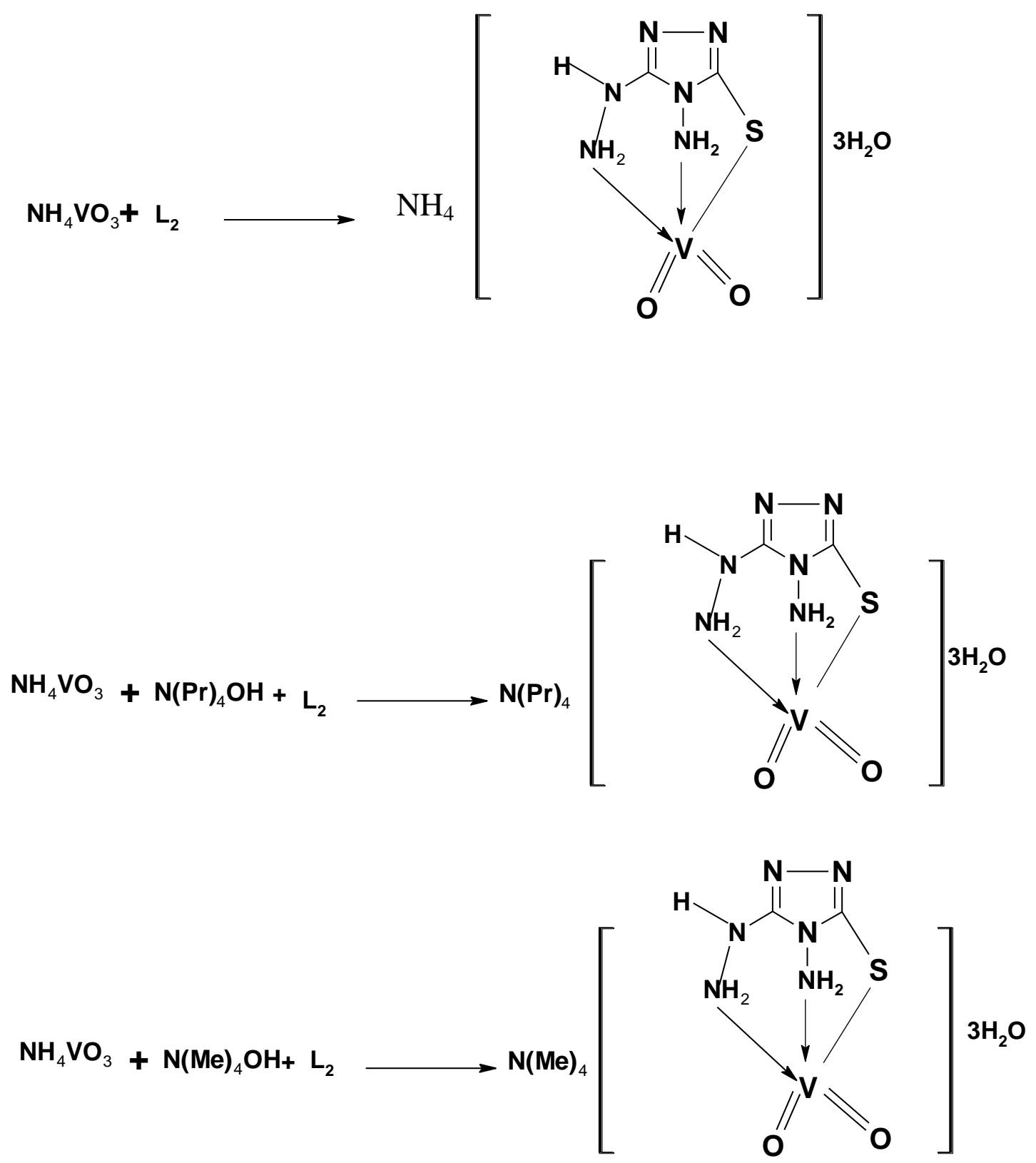

\section{Antimicrobial activity:-}

Scheme 2:-

The organic ligands and their prepared corresponding vanadium $(\mathrm{V})$ complexes were screened in vitro for the biological susceptibility against three strain Gram-positive bacteria Enterococcus faecalis, Staphylococcus aureus, and Group B streptococcus (GBS) and three Gram-negative bacteria Klebsiella pneumonia, Escherichia coli and Proteus Mirabilis in addition, to one kind of pathogenic fungus named Candida Albicans. The microbial activity method used in this study was well Diffusion method using DMSO as solvent and as a control[1]. The bacterial and fungal susceptibility was monitored by measuring the zones of inhibition (in $\mathrm{cm}$ ) around each hole at which the visible growth was completely inhibited. The results indicated that organic ligands $\left(\mathrm{L}_{1}\right.$ and $\left.\mathrm{L}_{2}\right)$ did not show any activity against nearly all types of bacteria.Some moderate activity was noticed against the fungusC.Albicans(inhibition zone of 0.9-1.12 cm). The tested vanadium complexes showed antifungal activity when used in the powder form against the pathogenic fungus $\mathrm{C}$. Albicans with highest sensitivity was noticed for the compound $\mathrm{N}(\mathrm{Pr})_{4}\left[\mathrm{VO}_{2}\left(\mathrm{~L}_{1}\right)_{2}\right] .3 \mathrm{H}_{2} \mathrm{O}$ with an inhibition zone $=1.60 \mathrm{~cm}$. $\mathrm{NH}_{4}\left[\mathrm{VO}\left(\mathrm{L}_{1}\right)_{2}\right] .3 \mathrm{H}_{2} \mathrm{O}$ and $\mathrm{NH}_{4}\left[\mathrm{VO}_{2}(\right.$ $\left.\left.\mathrm{L}_{2}\right)\right] .3 \mathrm{H}_{2} \mathrm{O}$ also showed less activity with an inhibition zone between $1.50-1.55 \mathrm{~cm}$ (figure 6). The observations indicated that theexamined vanadium $(\mathrm{V})$ complexes have moderate antifungal activity compared to the free ligands 
and did not show antibacterial activity. The increased antifungal activity of the vanadium complexes may be due to chelation that increases the permeability of the chemicals and may be the presence of vanadium ion [1]. Our results in this work were similar to other reported work of other researchers [37].

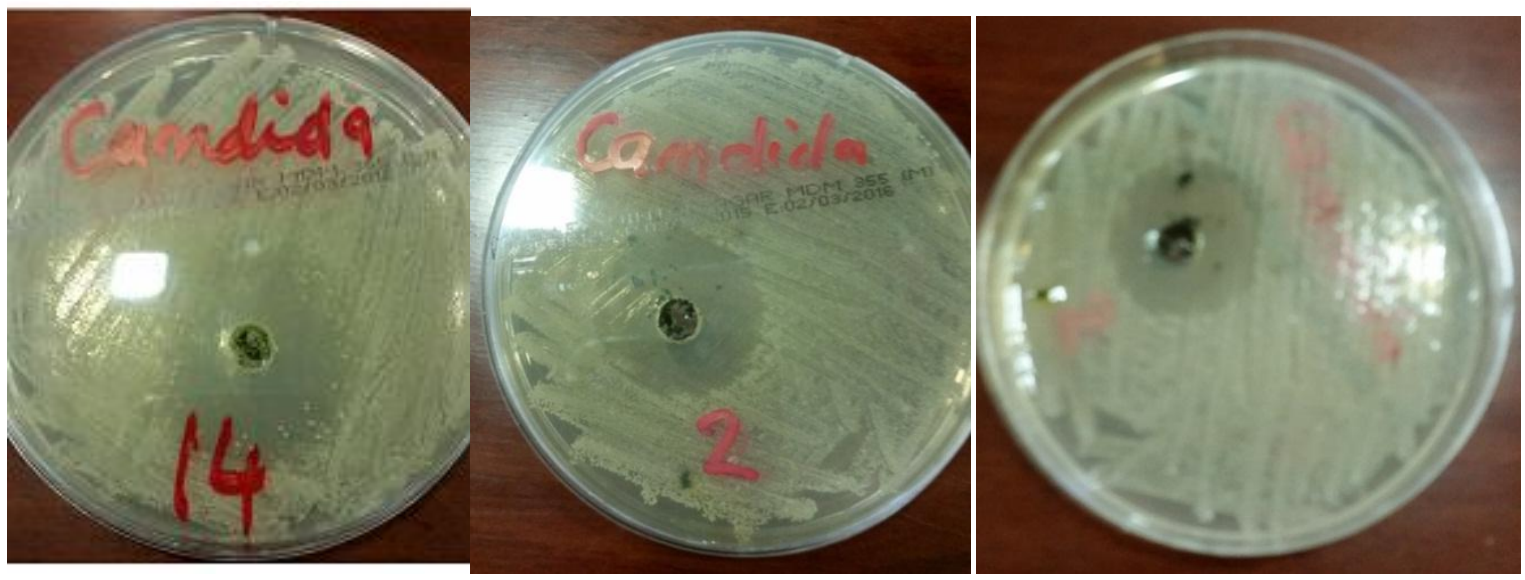

\section{Conclusion:-}

Fig. 6:- antifungal activity against the pathogenic fungus C. Albicans

Two series ofoxo-/dioxo-vanadium (V) complexes with bidentate (4-amino-5-mercapto-3-phenyl-1,2,4-triazole $\left(\mathbf{L}_{1}\right)$ ) and tridentate (4-Amino-3-hydrazino-5-mercapto-1,2,4-triazole $\left(\mathrm{L}_{2}\right)$ ) ligandswere prepared. The Vanadium (V) complexes were prepared by reacting an aqueous hot solution of $\mathrm{NH}_{4} \mathrm{VO}_{3}$ with methanolicsolution of the ligands in 1:2(M: $\left.\mathrm{L}_{1}\right)$ and 1:1 $\left(\mathrm{M}: \mathrm{L}_{2}\right)$ molar ratios. The ligands and their vanadium complexes were characterized using elemental analysis, IR, ${ }^{1} \mathrm{H}-\mathrm{NMR}$, electronic spectra and TGA studies. The observations and analysis results indicated that the complexes were of two monomeric typesoxo- and dioxo-vanadium (V) complexes. Vanadium (V) complexes with the bidentate ligand $\left(\mathrm{L}_{1}\right)$ were having one oxo group $(\mathrm{V}=\mathrm{O})$, while those complexeswith tridentate ligand $\left(\mathrm{L}_{2}\right)$ were having two oxo-groups $(\mathrm{V}=\mathrm{O})$. The proposed structureswere a distorted square pyramidal geometry for all the vanadium (V) complexes. The ligands and corresponding complexes were tested for their antimicrobial activity.The observations showed that the prepared vanadium (V) complexes were moderately have enhanced activity against $C$. albicansfungus compared to the free ligands. The ligands andtheir corresponding vanadium (V) complexes did not show any antibacterialactivity.

\section{Acknowledgement:-}

The author is gratefully acknowledged that this work was supported financially by Albaha University (Project No: 26/1435) and grateful to the Scientific Research Deanship at AlBaha University.

\section{References:-}

1. Zabin S and Abdelbaset M, Eur. J. Chem.,7 (3) (2016) 322.

2. Singh K, Kumar M, and Kumar V, International Journal of Chemical Science and Technology 6(1) (2016) 26.

3. Klingele M. H, Brooker S, Coord. Chem. Rev., 241, (2003) 119.

4. Haasnoot J.G., Coord. Chem. Rev., 200- 202, (2000) 131.

5. Aromi G., Barrios L.A., Roubeau O., Gamez P., Coord. Chem. Rev., 255, (2011) 485.

6. Nadeem H, Mohsin M, Afzaal H, Riaz S, Advances in Microbiology 3 (2013) 366.

7. Thakur A., Gupta P. S., kumarshukla P., Verma A, and Pathak P, Int. J. Curr. Res. Aca. Rev., 4(2) (2016) 277.

8. Patil B. S., Krishnamurthy G., Shashikumar N. D., Lokesh M. R., and BhojyaNaik H. S., J. Chem., (2013), 2-7.

9. Bayrak H., Demirbas A., Demirbas N., and Karaoglu S. A., Eur. J. Med. Chem., 44(11) (2009) 4362.

10. Padmavathi V., Thriveni P., Sudhakar Reddy G., and Deepti D., Eur. J. Med. Chem., 43(5) (2008) 917.

11. Soni B., Ranawat M. S., Sharma R., Bhandari A., and Sharma S., Eur. J. Med. Chem., 45(7) (2010) 2938.

12. Xu J., Cao Y., Zhang J., Eur. J. Med. Chem., 46(7) (2011) 3142.

13. Tozkpran B., Kupeli E., Yesilada E., and Ertan M., Bioorganic and Medicinal Chemistry 15(4) (2007) 1808.

14. Holla B. S., Veerandra B., Shivananda M. K., and Poojary B., Eur. J. Med. Chem., 38(7-8) (2003) 759.

15. Duran A., Dogan H. N., and Rollas S., Il Farmaco, 57( 7) (2002) 559.

16. Abdel-Aal M. T., El-Sayed W. A., El-Kosy S. M., and El-Ashry E. S. H., Archiv der Pharmazie-Chemistry in Life Sciences, 341(5) (2008) 307.

17. Kucukguzel I., Kucukguzel S. G., Rollas S., and. Kiraz M, Bioorg. Med. Chem. Lett., 11(13) (2001) 1703.

18. Foroumadi A., Kiani Z., and Soltani F., IlFarmaco, 58(11) (2003) 1073. 
19. Labanauskas L., Udrenaite E., Gaidelis P., and Brukštus A., IlFarmaco, 59(4) (2004)255.

20. Almasirad A., Tabatabai S. A., Faizi M, Bioorg. Med. Chem. Lett., 14(24) (2004) 6057.

21. Kucukguzel I., Kucukguzel S. G., Rollas S., IlFarmaco, 59 (11) (2004) 893.

22. Varvaresou A., Siatra-Papastaikoudi T., Tsotinis A., Tsantili-Kakoulidou A., and Vamvakides A., IlFarmaco, 53, 5 (1998) 320.

23. Modzelewska-Banachiewicz B., Banachiewicz J., Chodkowska A., Jagiełło-Wójtowicz E., and Mazur L., Eur. J. Med. Chem., 39(10) (2004) 873.

24. Kelvin Cooper and Kenneth Richardson, "Bistriazole antifungal agents.", U.K. patent application No.US 4466974 A, 1984.

25. Goss P.E., Breast Cancer Res. Treat. 49 (Suppl 1) (1998) S59-65.

26. Philip N. Edwards, and Michael S. Large, "(Substituted aralkyl) heterocyclic compounds." US patent 4,935,437, 1990.

27. Lang M., Batzl C., Furet P., Bowman R., Hausler A., Bhatnagar A., J. Steroid Biochem. Mol. Biol., 44 (4 - 6) (1993) 421.

28. Clemons M., Coleman R.E., Verma S., Cancer Treat. Rev. 30 (2004)325.

29. Kalshetty B. M., Gani R. S.,Karabasannavar S.S. \&.Kalashetti M.B, Global Journal of Science Frontier Research, Chemistry 13 Issue 2 Version 1.0 (2013).

30. Toragalmath S. S., Patil S. A., Unki S. N., Halasangi B. M. and Badami P. S., Der PharmaChemica, 7(6) (2015) 147.

31. Alias M., Seewan A. N., Shakir C., Mohammad F. I.,Int. J. Pharm., 4(2) (2014) 126.

32. Haddad R., Yousif E. and Ahmed A., SpringerPlus 2 (2013) 510.

33. Siddappa K, Shikkargol R. K. and Angadi S. D., proc Indian Natn. Sci.Acad, 75 (2) (2009) 73.

34. Abdul Hameed A., Hassan F., International Journal of Applied Science andTechnology 4 (2) (2014) 202.

35. Mahal A.; Abu-El-Halawa R.; Zabin S. A.; Ibrahim, M.; Al-Refai M.; Kaimari, T. World J. Org. Chem., 3(1) (2015) 1.

36. Begum A., Sreedhar B, Laxmi K, Mamatha P and Sarala Devi Ch., RJPBCS 5(1) (2014) 408.

37. Narayana B. and Gajendragad M. R., Tr. J. Chemistry 21 (1997) 71.

38. Singh, K.; Kumar, Y.; Puri, P.; Singh, G. Bioinorg Chem. Appl. (2012) 9.

39. Maurya M. R., Khurana S., Zhang W. and Rehder D., J. Chem. Soc., Dalton Trans., (2002) 3015.

40. Liu H.X., Wang W., Wang X., Tan, M.Y., J. Coord. Chem. 33(4) (1994) 347.

41. Asgedom G., Sreedhara A., Kivikoski J., Valkonen J., Rao C.P., J. Chem. Soc., Dalton Trans. (14) (1995) 2459

42. Hazra A., Kumar Barik A., Pal S., Gupta S., Roy S., Butcher R. J., Shie-Ming Peng, Lee G.H., Kar S. K., Polyhedron 26 (2007) 773.

43. Samanta S., Ghosh D., Mukhopadhyay S., Endo A., Weakley T. J. R., Chaudhury M., Inorg.Chem. 42 (2003) 1508.

44. Kwiatkowski E., Romanowski G., Nowicki W., Kwiatkowski M., Suwinska K., Polyhedron 22 (2003) 1009.

45. Howarth, O.W. and Hunt J.R., J. Chem. Soc., Dalton Trans. (9), (1979) 1388.

46. Hammam A. M., EL-Gahami M. A., Khafagi Z. A., AL-Salimi M. S. and Ibrahim S. A., J. Mater. Environ. Sci. 6 (6) (2015) 1596.

47. National Committee for Clinical Laboratory Standards. 1997. Performance standards for antimicrobial disk susceptibility tests. Approved standard M2-A6. National Committee for Clinical Laboratory Standards, Wayne, Pa.

48. Silvertistein R. M., Bassler G.C. and Morrill T.C, "Spectormetirc Identification of Organic Compounds", 4th Ed., John Wiley and Sons, 1981.

49. Shakir M., Parveen S., Begum N., and Azim Y., Polyhedron, 22(24) (2003) 3181.

50. Shakir M., Parveen S., Begum N., and Chingsubam P., Transition Met. Chem, 29 (2004) 196.

51. Xavier R. J., Gobinath E., Spectro ChimicaActa Part A: Molecular and Biomolecular Spectroscopy, 86 (2012) 242.

52. Guédira F., Castellà-Ventura M., Zaydoun S., Elhajji A., Lautié A., and Idrissi M. S., SpectrochimicaActa Part A: Molecular and Biomolecular Spectroscopy, 73(4) (2009) 738.

53. Zhao P. S., Ming Xu J., Zhang W. G., Jian F. F., and Zhang L., Struct. Chem, 18 (2007) 993.

54. Roubeau O., Gubbens P. C. M., Visser D., Blaauw M., Dalmas de Re'otier P., Yaouanc A., Haasnoot J.G., Reedijk J., Sakarya S., Jayasooriya U. A., Cottrell S. P., King P.J.C., Chem. Phys. Lett., 395(4-6) (2004) 177.

55. Mahajan S., Singh B., Sheikh H.N., Kalsotra B.L. Chem. Sci. Trans., 1(1) (2012) 23.

56. Licı'nia L.G. Justino, M. Lu1'sa Ramos, M. MadalenaCaldeira, Victor M.S. Gil. Inorg. Chim. Acta311 (2000) 119.

57. Refat M. S., El-Korashy S. A. and Hussien M. A., Canadian Chemical Transactions, 2 (1) (2014) 97.

58. MohanaPriyadarshini K., Chandramohan A., AnandhaBabu G., Ramasamy P., Optik 125 (2014) 1390.

59. Sanche-Lara, E., Sanchez-Lombardo I., Perez-Benitez A., Mendoza A., Alamo M. F., Vergara E. G., J. Clust. Sci. 26(3) (2015) 901. 